\title{
PERSPECTIVES ON ROMANTICISM
}


By the same author

MOTOWN AND THE ARRIVAL OF BLACK MUSIC ROMANTICISM: A Structural Analysis 


\section{PERSPECTIVES ON \\ ROMANTICISM}

A Transformational Analysis

David Morse

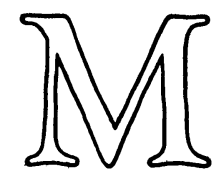


(C) David Morse 1981

Softcover reprint of the hardcover 1st edition 1981 All rights reserved. No part of this publication may be reproduced or transmitted, in any form or by any means, without permission

First published 1981 by THE MACMILLAN PRESS LTD London and Basingstoke Companies and representatives throughout the world

First published in the USA 1981 by BARNES \& NOBLE BOOKS 81 Adams Drive Totowa, New Jersey, 07512 DOI 10.1007/978-1-349-05262-2 
To Maxine 


\section{Contents}

Preface ix

Introduction $\quad$ xi

1. Romantic Discourse 1

2. From Protestantism to Romanticism 102

3. Smollett and the Articulation of Romantic Narrative $\quad 179$

4. Romanticism and the Infinite 213

5. Perspective on Perspectives 255

$\begin{array}{ll}\text { Notes } & 290\end{array}$

Index $\quad 306$ 
Of what a strange nature is knowledge! It clings to the mind, when it has once seized on it, like a lichen on the rock.

\section{Mary Shelley, Frankenstein}

For us, necessity is not, as of old, a sort of mythological personage without us, with whom we can do warfare. It is rather a magic web woven through and through us, like that magnetic system of which modern science speaks, penetrating us with a network, subtler than our subtlest nerves, yet bearing in it the central forces of the world.

Walter Pater, The Renaissance 


\section{Preface}

In writing the present book I have benefited from the assistance of a great number of people over a long period of time. I should like to thank the friends and colleagues who either discussed this project with me or offered their comments on sections of the manuscript: Stephen Bann, Jonathan Dollimore, Roy Edgley, Peter Nicholls, Angus Ross, Marcia Pointon, Peter Stallybrass. I feel I owe a particular debt to Angus Ross and Roy Edgley. Their reactions greatly aided me in developing and clarifying my own conceptions, but of course they bear no responsibility for what follows.

I am grateful to the University of Sussex, which enabled me to pursue my studies in greater depth by allowing me leave of absence, and furnished financial assistance towards the preparation of the manuscript for publication. I have also greatly benefited from the policy of Sussex University Library, which in the palmy days of yore wisely recognised that books exist to be read and allowed them to be borrowed wherever possible. The latitude and indulgence I have been accorded have been of inestimable value.

Since this book is addressed in the first instance to an English-language context I have given all passages from foreign-language works in translation, but I have tried to preserve the original titles where it seemed possible to do so without pedantry or affectation.

D. M.

The author and publishers wish to thank the following who have kindly given permission for the use of copyright material: John Calder (Publishers) Ltd for extracts from J. W. von Goethe, Sufferings of Young Werther, translated by B. Q. Morgan (1974); Cambridge University Press for extracts from 
J. G. Herder on Social and Political Culture, translated by F. M. Barnard (1969); and Oxford University Press for extracts from G. W. F. Hegel, Philosophy of Mind, translated by William Wallace (C) OUP 1971. 


\section{Introduction}

Perspectives on Romanticism is the first instalment of a composite study of Romanticism. It is designed to serve both as an introduction and complement to Romanticism: A Structural Analysis, which analyses the major fields of literary discourse between 1790 and 1830 . The present study moves crablike from there into other types of discourse in an endeavour to show how they are all interwoven. The opening chapter, 'Romantic Discourse', examines the theory of language and the theory of the subject and shows how various forms of knowledge, including the sciences, were organised. Chapter 2, 'From Protestantism to Romanticism', argues that Romanticism involves the displacement of Protestant criteria and concerns into the province of aesthetic theory. Chapter 3, 'Smollett and the Articulation of Romantic Narrative', shows how fiction becomes concerned to represent dynamic psychological processes and how they become codified in narrative structures. Chapter 4, 'Romanticism and the Infinite', examines the relationship between literature, music and painting. Chapter 5, 'Perspective on Perspectives', a somewhat ironic designation, examines the Romantic legacy of relativism and explores its implications for knowledge.

At the same time these studies do not all fall within the traditional confines of the Romantic period, but, Janus-like, look either backward towards the eighteenth century or forward to the nineteenth and twentieth. Analysis continually presses up against limits and boundaries where Romanticism is always on the point of becoming something else. It thus should be understood as a transformational analysis, since the methodological assumption that underpins it is that nothing ever begins, starts or has its origin, but, rather, that everything is produced by transformation out of something else. More specifically, intellectual structures are self-liquidating structures, since their constant orientation to phenomena on the 
margins of discourse ultimately produces a recentring and redefinition of discourse.

The study of transformation in fields of discourse brings with it its own problems, since, paradoxically, the very demonstration of change has the effect of abolishing difference. Just as a smooth gear-change is effected by coordinating the speed of two differentially spinning wheels, so a transformational analysis may elide difference at the very point where it seeks to demonstrate it. In the present case, the most helpful corrective that can be applied is to consider the relative scope and provenance of religion at different points in the time-scale. Thus, both John Dennis, writing around 1700, and Matthew Arnold, writing in the mid-nineteenth century, believe that poetry has a religious dimension, but, whereas Dennis believes that poetry should advance the cause of religion, Arnold believes that it should take its place. For an eighteenth-century student of language it was possible to regard the division of tongues at Babel as a real historical event, but this could scarcely have been a guiding hypothesis of nineteenth-century transformational linguistics. Smollett's Ferdinand Count Fathom has structural affinities with Conrad's Lord Jim, but Conrad would not have interpreted the action of his novel as exhibiting the workings of divine providence, as does Smollett. The pursuit of sensation figures as impiety in Mozart's Don Giovanni; for Pater it is dictated by the very nature of human existence.

If this book has a single concern it is as an analysis of the trajectory of Western culture from the Reformation to the present, in which relativism and the development of multiple perspectives has threatened long-established notions of correspondence and truth. But, of course, culture has no single trajectory but must rather be considered as an ensemble of trajectories, like patterns of tracer fired at night. For, in answer to the general and repeated question 'How did we get here from there?', there is always another 'here', another 'there' and another 'we'. And, in collapsing telescope-like the distance between the two, we should never cease to remind ourselves not only that the view is different from the other end, but also that the telescope itself is always trained on different objects of inquiry.

Our understanding of the past and our understanding of 
the present are constructed simultaneously in our recognition of difference. We recognise the discourse of another culture in its collision with our own. Perhaps with Romanticism this is especially difficult, since Romanticism has given us so many of the terms from which our own discourse is constructed: ideology, the unconscious, the opposition between self and society, the notion of the author as a source - so that our recognition is only truly a recognition if it is also seen as a misrecognition.

If there is one particular misrecognition that I would want to avert in the present case, it is that the analysis of structures presented here should be understood as a presentation of themes. Thematic analysis of a certain kind has done much to weaken the spirit of inquiry in the human sciences. The intellectual traveller sets forth with his knapsack and after traversing a large and difficult terrain returns bearing his knapsack as fruit and evidence of his journey. The particular intersection through history that has been chosen slices so cleanly that it bears no traces of the materials it has severed. The investigator fails to understand the parameters both of his own discourse and of those he studies, and switches without blush or blink from one to the other. He offers an illustration of contemporary understanding through an assortment of curious material gathered from the past, a sort of beachcombing on the shores of time - so that what we learn is what we know already.

In structuring our understanding of the past in our own terms, we have to recognise that that past was structured differently for others; the opening and closing of the gap between the two is knowledge. 